\title{
Reciprocal regulation of PCGEM1 and miR-145 promote proliferation of LNCaP prostate cancer cells
}

Jin-Hua He ${ }^{1 \dagger}$, Jing-zhi Zhang ${ }^{2+}$, Ze-Ping Han ${ }^{1}$, Li Wang ${ }^{1}$, Yu Bing Lv ${ }^{1}$ and Yu-Guang Li ${ }^{1 *}$

\begin{abstract}
Prostate cancer gene expression marker 1 (PCGEM1) is a long non-coding RNA (IncRNA) overexpressed in prostate cancer (PCa) cells that promotes PCa initiation and progression, and protects against chemotherapy-induced apoptosis. The microRNA miR-145 functions as a tumor suppressor in PCa. We speculate that reciprocal regulation of PCGEM1 and miR-145 promote proliferation of LNCaP prostate cancer cells. To test this hypothesis, the interaction between PCGEM1 and miR-145 was examined using a luciferase reporter assay. Expression levels were selectively altered in LNCaP cells and noncancerous RWPE-1 prostate cells by transfection of miR-145 or small interfering RNA sequences against (siRNA) PCGEM1. Relative expression levels were detected by RT-PCR, tumor cell growth and early apoptosis by the MTT assay and flow cytometry, respectively, and tumor cell migration and invasion properties by transwell assays. The effect of siRNA PCGEM1 and miR-145 transfection on prostate cancer growth in vivo was examined in the (nu/nu) mouse model. PCGEM1 and miR-145 exhibited reciprocal regulation; downregulation of PCGEM1 expression in LNCaP cells increased expression of miR-145, while overexpression of miR-145 decreased PCGEM1 expression. Transfection of the miR-145 expression vector and siRNA PCGEM1 inhibited tumor cell proliferation, migration, and invasion, and induced early apoptosis both in vitro. In contrast, there was no effect on RWPE-1 cells. We demonstrate a reciprocal negative control relationship between PCGEM1 and miR-145 that regulates both LNCaP cell proliferation and nu/nu PCa tumor growth. The results also identify PCGEM1 and associated regulators as possible targets for PCa therapy.
\end{abstract}

Keywords: Long non-coding RNA, MicroRNA-145, Prostate cancer gene expression marker 1, Prostate cancer cells, Small interfering RNA sequences, Reciprocal regulation

\section{Background}

Long non-coding RNAs (lncRNAs) are untranslated transcripts longer than 200 nucleotides baring many of the structural characteristics of mRNAs, including a polyA tail, $5^{\prime}$-capping, and a promoter structure, but no conserved open reading frame [1-6]. Many lncRNAs are expressed at specific times and in specific tissues during development, and exhibit a variety of slicing patterns. It has been proposed that IncRNAs are involved in the epigenetic regulation of coding genes, and thus exert a powerful effect on a number of physiological and pathological

\footnotetext{
*Correspondence: lyg_py@126.com

${ }^{\dagger}$ Equal contributors

'Department of Laboratory, Central Hospital of Panyu District, 8 Fuyu Dong Road, shiqiao, Guangzhou, Guangdong 511400, P R China

Full list of author information is available at the end of the article
}

processes, including the pathogenesis of many human cancers [7-11].

MicroRNAs (miRs) are small noncoding RNAs usually 20-22 nucleotides long. To date, close to 1000 human miRs have been identified. Collectively, miRs are thought to regulate more than $50 \%$ of all human genes by binding to mRNA sequences and repressing expression, either by inhibiting translation or promoting RNA degradation [12-17].

Given the structural similarly with mRNAs, lncRNAs may be another important member of the non-coding RNA family [18]. The interaction between lncRNAs and miRs has been linked to the invasion and metastasis of tumors [19]. For example, the miR-29a epigenetically modulated expression of the IncRNA MEG3 in hepatocellular carcinoma (HCC) through promoter hypermethylation [20]. Loss of miR-31 expression in triple-negative 
breast cancer (TNBC) lines is attributed to hypermethylation of its promoter-associated CpG islan. MicroRNA-31 anchors the novel lncRNA LOC554202 and adjusts its transcriptional activity [21]. Moreover, the lncRNA HULC can inhibit the expression of the tumorigenic miR-372 [22].

Prostate cancer gene expression marker 1 (PCGEM1) is part of a novel class of androgen-regulated lncRNAs [23]. Overexpression in prostate cancer (PCa)-derived LNCaP cells promotes proliferation and a dramatic increase in colony formation [24,25]. Many miRs function as oncogenes or tumor suppressors in human cancers [26-32]. Downregulation of miR-145 has been reported in $\mathrm{PCa}$, suggesting that $m i R-145$ functions as a tumor suppressor [33]. Using the biology information software RegRNA (http://regrna.mbc.nctu.edu.tw/), we predicted that 48 distinct miRs bind to PCGEM1. Further online comprehensive analysis (http://cbio.mskcc.org/cancergenomics/prostate/data/) indicates that $96 \mathrm{miRs}$ are associated with $\mathrm{PCa}$. Clustering intersection analysis also linked miR-145 with PCa. Significantly, miR-145 has a binding site for lncRNA; thus, reciprocal regulation of PCGEM1 and miR-145 may promote or suppress PCa cell proliferation [34]. In this study, we explored possible mutual regulation of PCGEM1 and miR-145 expression in prostate cancer and the impact on PCa cell proliferation and invasive capacity.

\section{Materials and methods \\ Materials}

Non-cancerous RWPE-1 cells, HEK293T cells and LNCaP cells were purchased from the Shanghai Institute of Cell Biology (Shanghai, China). RPMI 1640 medium, fetal bovine serum (FBS), and Lipofectamine 2000 were obtained from Invitrogen (Carlsbad, CA, USA). The restriction enzymes NotI and Xhol, T4 DNA ligase, and reagents for RT-PCR were purchased from TaKaRa (Takara BioInc, Shiga, Japan). 3-(4,5-Dimethylthiazol-2-yl)-2,5-diphenyltetrazolium bromide (MTT), annexin-V-FITC, and propidium iodide (PI) were purchased from Sigma Chemical (USA), and negative control sequences and negative control inhibitor sequences were purchased from Ruibo Company (Shanghai, China).

\section{Design and construction of eukaryotic expression vector for hsa-miR-145}

The mature hsa-miR-145 sequence (5'-GUCCAGUUU CCCAGGAAUCCCU-3') is available from the miRNA Registry (MIMATOOOO437). To prevent formation of a termination signal, TTGGCCACTGACT was selected as the region in a $\mathrm{miR}$ expression vector template. The sequence TGCT was added to the $5^{\prime}$ positive-sense strand template of the miR expression vector and GTCC to the $5^{\prime}$ antisense strand template. Further, a nonspecific sequence was designed and sent to Shanghai GenePharma
Co, Ltd. for synthesis. The assay was according to previously described [35]. The eukaryotic expression vector plasmid targeting hsa-miR-145 was named pmiR-145.

\section{Design and synthesis of siRNA}

siRNAs are methylated 21 bp double-stranded RNA oligonucleotides. It uses gene-specific targets for RNAi analysis and reports up to 10 top scoring siRNA targets. The freeze-dried siRNAs were dissolved in RNase-free water and stored as aliquots at $-20^{\circ} \mathrm{C}$. The siRNA sequence of PCGEM1 (sense: 5 '-GCCCUACCUAUGAUU UCAUAU-3', antisense: 5' -AUAUGAAAUCAUAGGUA GGGC-3') and negative control sequence (sense: $5^{\prime}$-UU CUCCGAACGUGUCACGUUUC-3' antisense: 5' -GAAA CGUGACACGUUCGGAGAA-3') were synthesized by Shanghai GenePharma (Shanghai, China).

\section{Grouping and cell transfection}

The experimental culture groups included 1) untransfected LNCaP and RWPE-1 cells (control groups), 2) cells transfected with pmiR-145 or miR-145 mimics $(1.6 \mu \mathrm{g} / \mathrm{ml}$ and $50 \mathrm{nM}$, respectively), 3) cells transfected with the scrambled nucleotide sequence and empty vector (negative control or NC groups, $50 \mathrm{nM}$ ), 4) cells transfected with a miRNA inhibitor (NI group, $100 \mathrm{nM}$ ), 5) a negative control for NI (NCI group, $50 \mathrm{nM}$ ), 6) cells transfected with siRNA PCGEM1 sequence (siRNA PCGEM1 group, $50 \mathrm{nM}$ ). Cells in log phase growth were seeded on 6 -well culture plates $\left(2 \times 10^{5}\right.$ cells/well $)$ and transfected when the cell fusion rate reached $70 \%$. The DNA Lipofectamine 2000 or RNA Lipofectamine 2000 compound was added according to the manufacturer's instructions (Invitrogen). After $6 \mathrm{~h}$, the transfection medium was discarded. Cells were washed with serumfree RPMI 1640 and then cultured in RPMI 1640 supplemented with $10 \%$ FBS.

\section{Luciferase reporter assay}

The whole mRNA sequences of the PCGEM1 gene were obtained by PCR amplification and cloned separately into multiple cloning sites of the psi-CHECKTM-2 luciferase miRNA expression reporter vector. HEK293T cells were transfected with miR-145 mimic, miR-145 inhibitor, a control miRNA, a miRNA inhibitor control, or empty plasmid using Lipofectamine 2000 according to the manufacturer's instructions. Nucleotide-substitution mutation analysis was carried out using direct oligomer synthesis of PCGEM1 sequences. All constructs were verified by sequencing. Luciferase activity was measured using the dual luciferase reporter assay system kit (Promega Co, Madison, WI, USA) according to the manufacturer's instructions on a Tecan M200 luminescence reader. 


\section{Quantitative real-time RT-PCR}

Total RNA samples were extracted using Trizol (Invitrogen, CA) according to the manufacturer's instructions. Real-time quantitative PCR analysis was performed using an Applied Biosystems 7500 Real-Time PCR Systems (Applied Biosystems, Foster City, CA). The expression level of $18 S$ was used as an internal control for mRNAs, and $U 6$ level as an internal control for miRNAs. Primers used in quantitative real-time PCR analysis were: $U 6$ (forward: 5'-CTCGCTTCGGCAGCACA -3', reverse: 5'AACGCTTCACGAATTTGCGT-3'); $18 S$ (forward: $5^{\prime}$-CC TGGATACCGCAGCTAGGA-3', reverse: 5'-GCGGCG CAATACGAATGCCCC-3'); miR-145 (RT primer: $5^{\prime}$ CTCAACTGGTGTCGTGGAGTCGGCAATTCAGTTG AGTTCCCAT-3', forward: 5'-ACACTCCAGCTGGG GTCCAGTTTTCCCAGGAA-3', reverse: $5^{\prime}$-CTCAAC TGGTGTCGTGGA-3'); PCGEM1 (forward: 5' -CACG TGGAGGACTAAGGGTA-3', reverse: $5^{\prime}$-TTGCAACA AGGGCATTTCAG-3'); The expression level was calculated using $C T$ and $2^{-\Delta \Delta C t}$.

\section{MTT assay}

The viability of LNCaP and RWPE-1 cells was determined by MTT assay. Briefly, cells at $5 \times 10^{4} / \mathrm{ml}$ were transfected with siRNA PCGEM1 (siRNA PCGEM1 groups, $50 \mathrm{nM}$ ), empty plasmid and scramble sequence (negative control group, $1.6 \mu \mathrm{g} / \mathrm{ml}$ ), or pmiR-145 (pmiR145 group, $1.6 \mu \mathrm{g} / \mathrm{ml}$ ) in the presence of Lipofectamine 2000 and serum-free RPMI 1640 media for $6 \mathrm{~h}$. Cells were plated in 96-well plates in medium containing $10 \%$ FBS for another 24, 48, or $72 \mathrm{~h}$. MTT stock solution (20 $\mu \mathrm{l}, 5 \mathrm{mg} / \mathrm{ml})$ was added to each well for a final MTT concentration of $0.45 \mathrm{mg} / \mathrm{ml}$ and the plate was incubated for $4 \mathrm{~h}$ at $37^{\circ} \mathrm{C}$. Media was then removed and dimethylsulfoxide (DMSO) $(150 \mu \mathrm{l}$ added to dissolve the blue formazan crystals (the product of MTT conversion by viable cells) at room temperature for $30 \mathrm{~min}$. The relative change in viable cell number was estimated by absorbance at $570 \mathrm{~nm}$ on a Bio-Rad microtiter plate reader (Hercules, CA, USA).

\section{Flow cytometry assay}

LNCaP and RWPE- 1 cells were seeded at $1.0 \times 10^{6} / \mathrm{ml}$ in 24-well plates (Costar) and transfected in $500 \mu \mathrm{l}$ media/ well siRNA PCGEM1 (siRNA PCGEM1 groups, $50 \mathrm{nM}$ ), empty plasmid and scramble sequence (negative control group, $1.6 \mu \mathrm{g} / \mathrm{ml}$ ), or pmiR-145 (pmiR-145 group, $1.6 \mu \mathrm{g} / \mathrm{ml}$ ) by Lipofectamine 2000 reagent (Invitrogen) in serum-free RPMI 1640 for $6 \mathrm{~h}$. After transfection, $500 \mu \mathrm{l}$ of the appropriate growth medium containing $20 \%$ FBS were added to each well. Cells were incubated for another $48 \mathrm{~h}$ then harvested, washed twice with PBS, fixed with $70 \%$ ethanol, and treated with RNase A $(1 \mathrm{mg} / \mathrm{ml})$. Finally, the cells were double-stained with
FITC-conjugated annexin-V and propidium iodide (PI) solution $(50 \mu \mathrm{g} / \mathrm{ml})$. For each sample, data from approximately 10000 cells were recorded in the list mode on logarithmic scales. Apoptosis and necrosis were analyzed by quadrant statistics on double negative, annexin- $\mathrm{V}-$ positive/PI-negative, annexin-V-negative/PI-positive, and double-positive cells.

\section{Migration and invasion assay}

Cells were transfected with siRNA PCGEM1 (siRNA PCGEM1 groups, $50 \mathrm{nM}$ ), empty plasmid and scramble sequence (negative control group, $1.6 \mu \mathrm{g} / \mathrm{ml}$ ), or pmiR145 (pmiR-145 group, $1.6 \mu \mathrm{g} / \mathrm{ml}$ ) by Lipofectamine 2000 reagent in serum-free RPMI 1640 for $6 \mathrm{~h}$. One day after transfection, $1 \times 10^{5}$ cells were collected, resuspend in $100 \mu \mathrm{l}$ basal medium, and transferred to the transwell chamber. A $600 \mu \mathrm{l}$ volume of complete medium was added to the well and the chamber inserted. Plates were incubated at $37^{\circ} \mathrm{C}$ for $48 \mathrm{~h}$. Remaining cells were swabbed from the top transwell membrane filter and the chamber submerged in $4 \%$ paraformaldehyde for $20 \mathrm{~min}$. Cells in the well were stained with crystal violet for $10 \mathrm{~min}$, washed in PBS buffer, then counted by light microscope to determine transwell migration.

The transwell assay was performed as above except with Matrigel in the wells of 24-well plates. The Matrigel was first incubated in pre-chilled basal medium $(40 \mu \mathrm{l})$ at $37^{\circ} \mathrm{C}$ for $2 \mathrm{~h}$. The excess medium was discarded, $100 \mu \mathrm{l}$ basal medium added to the well with the Matrigel and $600 \mu \mathrm{l}$ to the chamber, following by incubation at $37^{\circ} \mathrm{C}$ overnight. Transfected cells $\left(1 \times 10^{5}\right)$ were resuspend in $100 \mu \mathrm{l}$ basal medium and transfer to the transwell chamber. Then, $600 \mu \mathrm{l}$ complete medium was added to the well and the chamber inserted. The plates were incubated at $37^{\circ} \mathrm{C}$ for 24 or $48 \mathrm{~h}$. Cells were stained with crystal violet for $10 \mathrm{~min}$, washed with the PBS and counted using an inverted microscope.

\section{In vivo treatment}

$\mathrm{BalB} / \mathrm{c}(\mathrm{nu} / \mathrm{nu})$ mice from the Animal Center of Guangzhou Province (Guangdong, China) received subcutaneous injections of $2 \times 10^{6} \mathrm{LNCaP}$ cells into each axilla area. When xenograft tumors became palpable (about $0.1 \mathrm{~mm}^{3}$ ), mice were randomly divided into the control group receiving PBS injection $(100 \mu \mathrm{l})$, siRNA PCGEM1 (500 nM), negative control (plasmid, scramble sequence $16 \mu \mathrm{g})$, PmiR-145 (16 $\mu \mathrm{g})$, with 6 mice each group. There was no difference in baseline tumor size between the groups. Tumor volume was calculated every 3 days according to the formula $v=a b 2 \pi / 6$, where "a" is the maximum tumor diameter and " $\mathrm{b}$ " the minimum diameter. After treatment for $20 \mathrm{~d}$, mice were euthanized and tumors were dissected and weighed. 


\section{Data analysis}

All results are the averages of at least three independent experiments from separately treated and transfected cultures. Data are expressed as the mean \pm SD. Statistical comparisons were made by one-way analysis of variance (ANOVA). $\mathrm{P}<0.05$ was considered to indicate a statistically significant difference.

\section{Results}

miR-145 regulates PCGEM1 expression by binding to the PCGEM1

ReRNA, an lncRNA target miR prediction software, predicted miR-145 binding sites at 983 bp and 1004 bp in the PCGEM1 (Figure 1C). The full-length sequence of PCGEM1 (1643 bp) was cloned downstream of the luciferase gene in the psiCHECK carrier to construct the psiCHECK-2-PCGEM1 carrier. Co-transfection of HEK293T cells with miR-145 mimics was performed to detect the binding site on the PCGEM1 (983-1004 bp). The co-transfection of HEK293T cells with miR-145 mimics and psiCHECK-2-PCGEM1 also significantly inhibited luciferase activity $(P<0.05)$ (Figure 1A); however, co-transfection of HEK293T cells with miR145 mimics and empty psiCHECK-2 had little effect on the activity of luciferase $(P>0.05)$ (Figure $1 \mathrm{~B})$. We concluded that miR-145 can regulate the expression of PCGEM1 by directly binding to target sites within the PCGEM1 sequence.
The miR-145 and PCGEM1 expression in in the LNCaP cells exhibited reciprocal regulation

To examine possible mutual regulation of PCGEM1 and $m i R-145$, we designed a small interfering RNA sequences to knockdown PCGEM1 expression and detected the expression levels of miR-145. Alternatively, we transfected PmiR-145 into LNCaP cells and then detected the expression levels of PCGEM1. Transfection of the siRNA PCGEM1 downregulated expression of PCGEM1 and resulted in a significant increase in miR-145 expression compared to the $\mathrm{NC}$ group and control group (both $\mathrm{P}<0.05$ ) (Figure 2).

siRNA-mediated PCGEM1 knockdown and miR-145 overexpression inhibited LNCaP proliferation

To examined the effect of siRNA-mediated PCGEM1 knockdown and concomitant overexpression of miR-145 on PCa cell proliferation, normal prostate cells (RWPE-1) and LNCaP cells were transfected as above and cell numbers estimated by MTT after 24, 48, $72 \mathrm{~h}$. Indeed, both siRNA PCGEM1 and PmiR-145 transfection groups exhibited a significant reduction in LNCaP cell proliferation, while transfection with empty vector and scrambled sequences (negative control group) had no effect compared to untransfected controls (Figure 3A). In contrast, proliferation of RWPE-1 cell was not changed significantly, even after $72 \mathrm{~h}$ (Figure $3 \mathrm{~B}$ ).
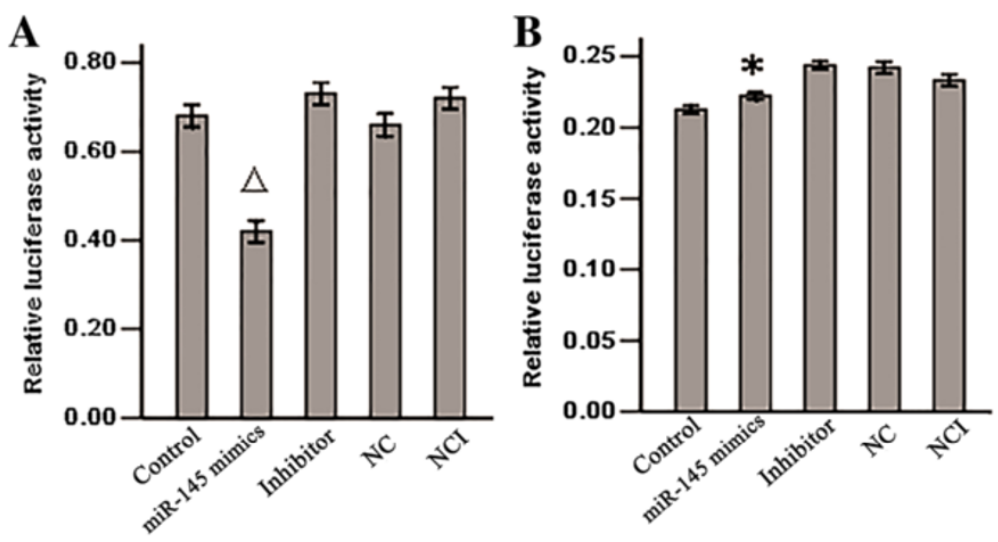

\section{C miR-145 3'UCCCUAAGGACCCUUUUGACCUG 5' \\ II:III| |111111 \\ 3'UTR(983-1004) 5'CATATTITCTGTGTAACTGGAT 3'}

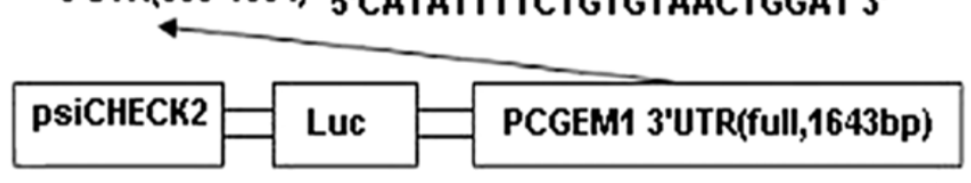

Figure 1 The interaction between miR-145 and PCGEM1 was detected by sensor reporter. A: Comparison of luciferase activity of plasmid transfected cloned PCGEM1 $\left(\mathrm{P}^{\Delta}<0.05\right)$ vs control and NC. B: The luciferase activity comparison of empty psiCHECK-2 (P* $\left.>0.05\right)$ vs control and NC, IN, NC, NCl group. C: The target sequence for miR-145 at 1: Control group; 2: miR-145 mimics group; 3: inhibitor group; 4: NC group; 5: NCl group. 

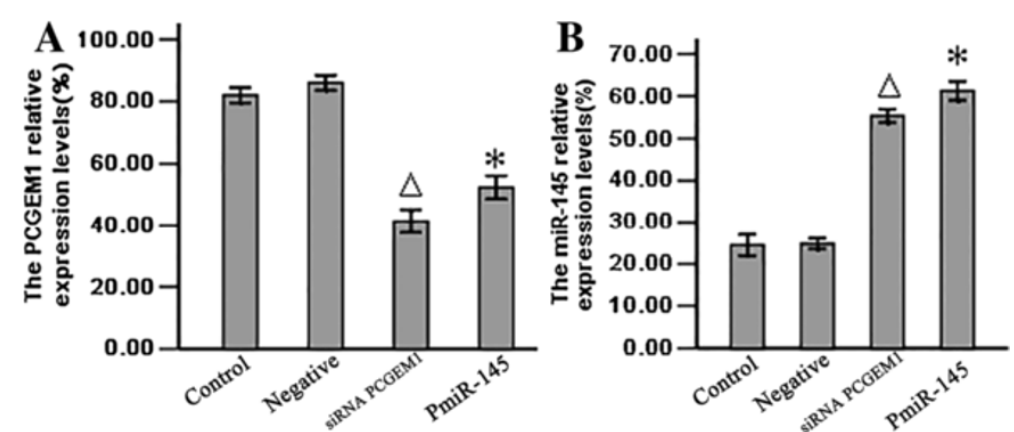

Figure 2 The relative expression levels of PCGEM1 and miR-145. A: The PCGEM1 mRNA expression levels were determined by Real time RT-PCR, $\mathrm{P}^{\Delta^{*}}<0.05$ vs control and NC group. B: The miR-145 expression levels determined by Real time RT-PCR, $\mathrm{P}^{\Delta^{*}}<0.05$ vs control and NC group. 1: Control group; 2: Negative group: 3: siRNA PCGEM1 group. 4. PmiR-145 group.

siRNA-mediated PCGEM1 knockdown and miR-145 overexpression induced early apoptosis of LNCaP cell Cell apoptosis of the above transfection groups was detected by flow cytometry using annexin-V/PI double staining. In total, $25.16 \%$ of PCGEM1 knockdown and $23.6 \%$ of miR-145-overexpressing LNCaP cells were in early apoptosis (Figure 4A, C), compared to only $0.63 \%$ and $0.82 \%$ of RWPE- 1 cells, respectively, in these same transfection groups (Figure 4B, D).

\section{siRNA-mediated PCGEM1 knockdown and miR-145 overexpression decreased LNCaP cell migration and} invasion

Transwell migration assays revealed that PCGEM1 knockdown led to a mean $46 \pm 8.6 \%$ decrease in $\mathrm{LNCaP}$ cell migration, and miR-145 overexpression to a mean $36 \pm 7.8 \%$ decrease (Figure 5A), while these treatments had no effect on REWP-1 cell migration (Figure 5B). The effect of siRNA PCGEM1/PmiR-145 on LNCaP cell invasion was evaluated using Matrigel-coated Transwell invasion assays. siRNA PCGEM1 led to a mean $52 \pm 6.6 \%$ decrease in LNCaP cell invasion and pmiR-145 led to a mean $59 \pm$ 6.3\% decrease in LNCaP cell invasion (Figure 5C). siRNA PCGEM1 and PmiR-145 have no effects on RWPE-1 cell invasion (Figure 5D).

\section{siRNA-mediated PCGEM1 knockdown and miR-145 overexpression inhibits progression of tumor xenografts}

LNCaP tumor xenografts were established in Athymic nude mice to evaluate the effects of siRNA PCGEM1 or pmiR-145 on prostate cancer growth in vivo. Compared to the untreated animals, application of siRNA PCGEM1 or pmiR-145 significantly diminished the tumor volume, whereas negtive control group had no effect (Figure 6). No body weight loss or diarrhea was observed and all animals (treated as well as non-treated) survived. The results shows that shows that reduce the expression of PCGEM1
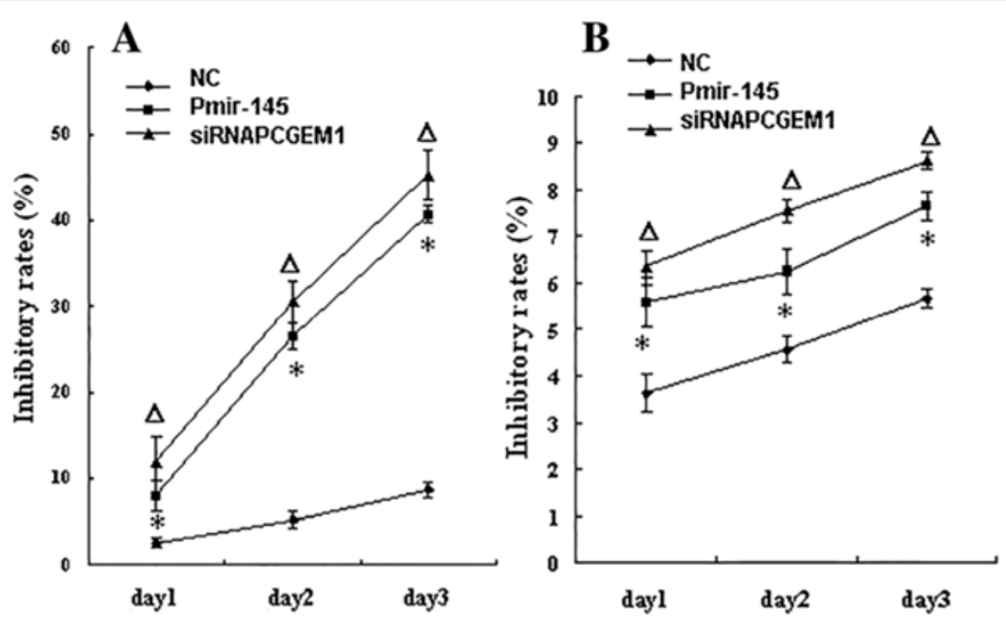

Figure 3 The viability of cells determind by MTT assay. LNCaP cells after transfection, the cells were plated in 96-well plates in medium containing $10 \%$ FBS for another 24, 48, 72 hour. Cell viability was assessed by MTT assays. Mean values of three independent experiments with standard errors are represented. A: The inhibitory rates of $\mathrm{LNCaP}$ cells, $\mathrm{P}^{*}<0.05 \mathrm{Vs}$ NC group. B: The inhibitory rates of RWPE-1cells, $\mathrm{P} \Delta^{*}>0.05$ vs NC group. 


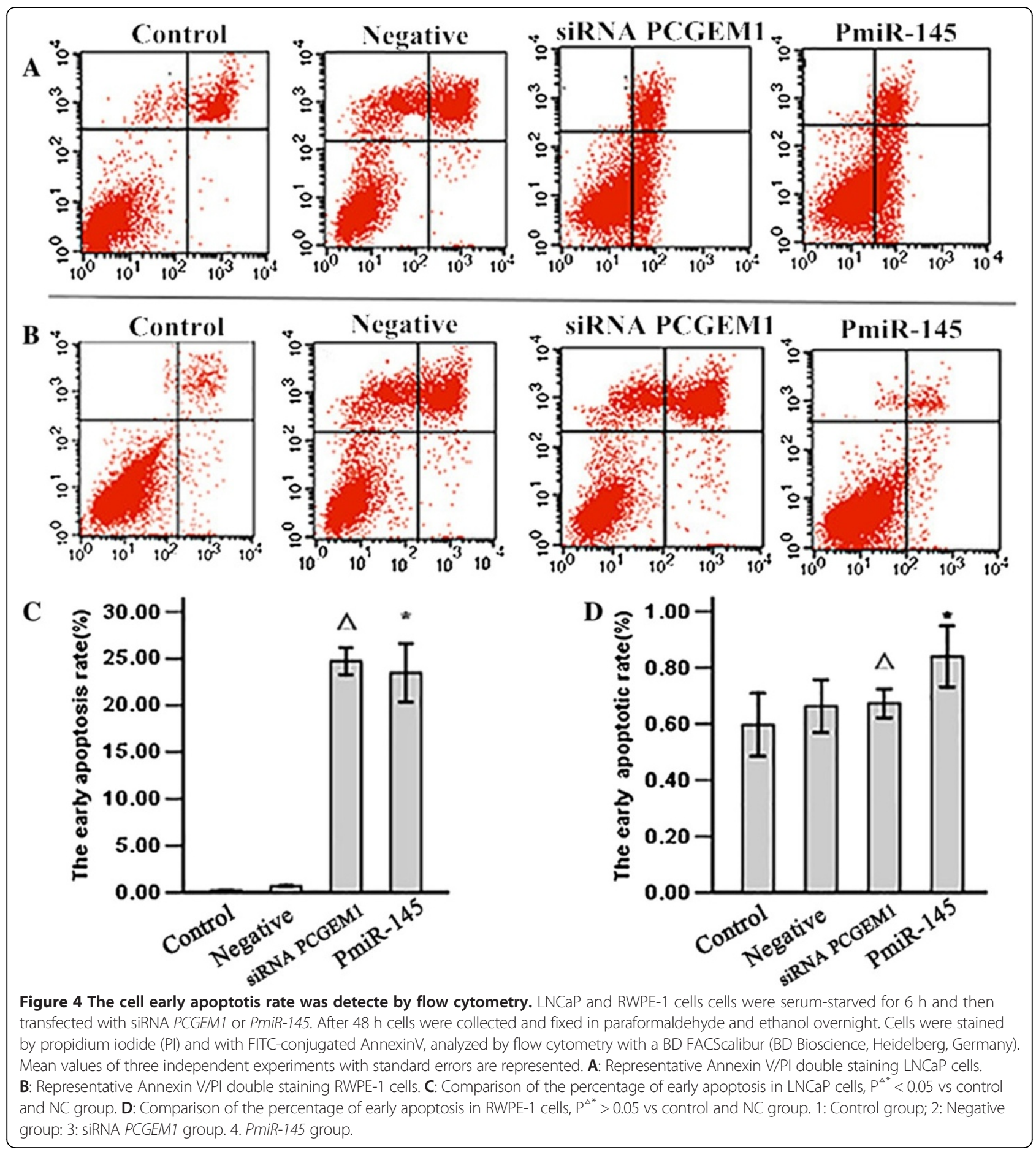

or over express $m i R-145$ can effectively inhibit prostate cancer growth in vivo.

\section{Discussion}

Long non-coding RNAs (lncRNAs) are a new class of regulatory RNA [36]. These mRNA-like molecules, which lack significant protein-coding capacity, were once thought to be a part of the genomic "dark matter", but recent studies have implicated lncRNAs in a wide range of biological functions through poorly understood molecular mechanisms [37]. Despite recent insights into how lncRNAs function in such diverse cellular processes as regulation of gene expression and assembly of cellular structures, by and large, the key questions regarding 

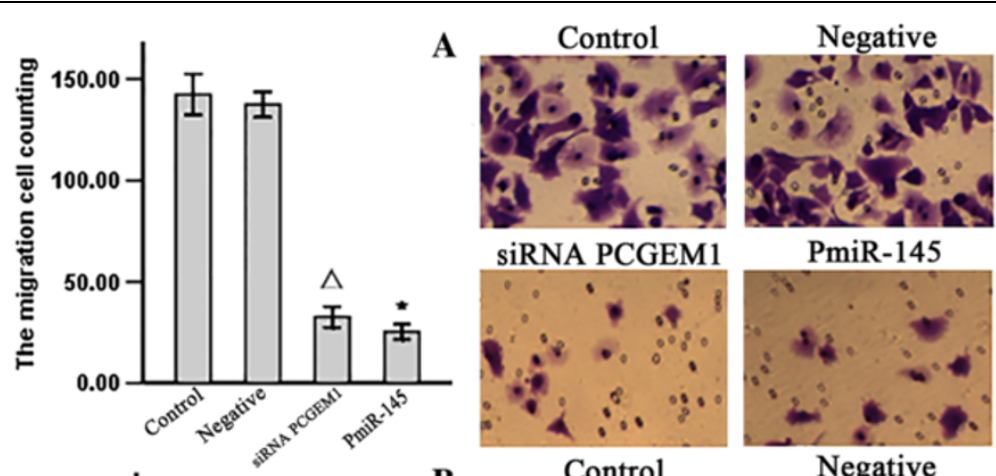

PmiR-145
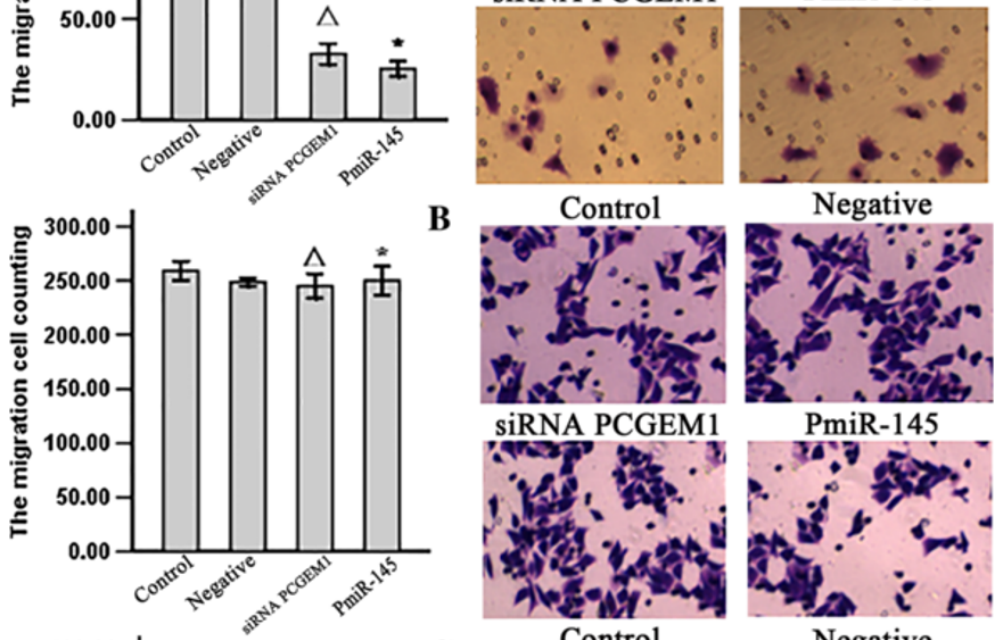

Negative

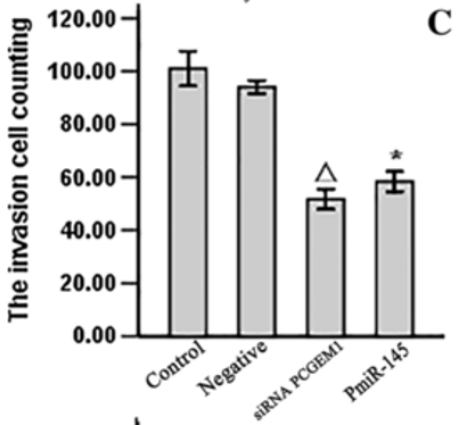

C
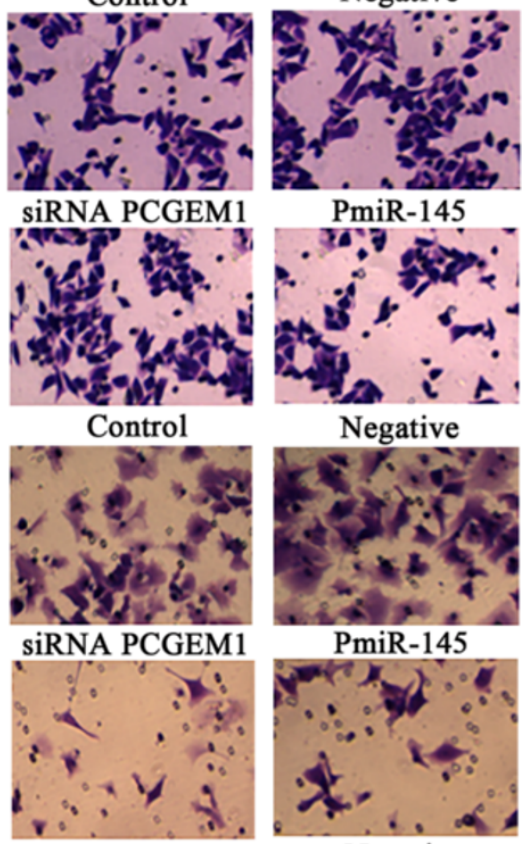

Negative

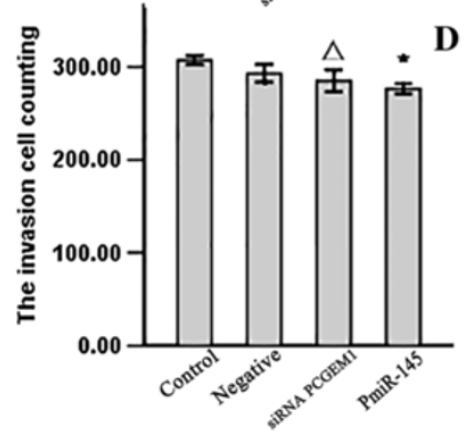

Control
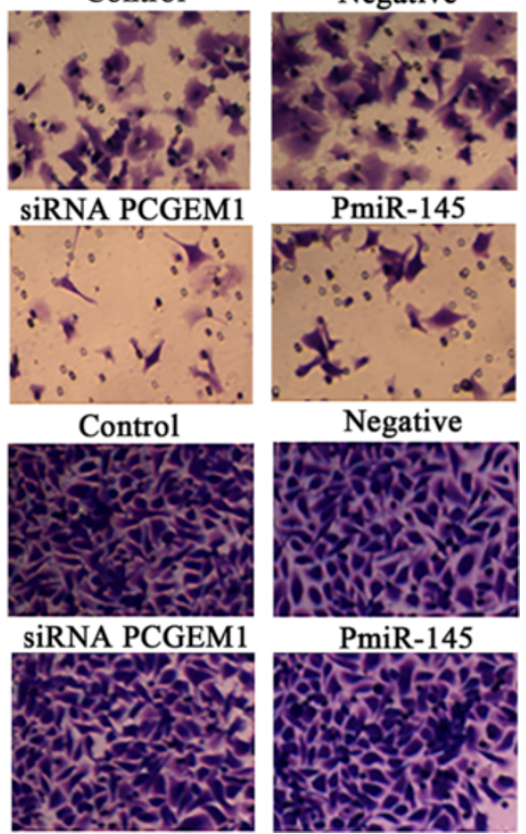

Figure 5 Effect of siRNA PCGEM1/PmiR-145 on cell migration. After $48 \mathrm{~h}$, migrated and invasion cells were fixed, stained, and counted. siRNA PCGEM1 and PmiR-145 significantly decreased LNCaP cell migration and invasion and have no effcets on RWPE-1 cell migration. A: a Transwell migration assay was done on LNCaP cells with siRNA PCGEM1 and PmiR-145. $P^{\Delta *}<0.05$ vs control and NC group. B: a Transwell migration assay was done on LNCaP cells with siRNA PCGEM1 and PmiR-145. $P^{\star *}>0.05$ vs control and NC group. C: a Transwell invasion assay was done on LNCaP cells with siRNA PCGEM1 and PmiR-145. $P^{\Delta *}<0.05$ vs control and NC group. D: a Transwell invasion assay was done on LNCaP cells with siRNA PCGEM1 and PmiR-145. $P^{\Delta *}>0.05$ vs control and NC group 1: Control group; 2: Negative group: 3: siRNA PCGEM1 group. 4. PmiR-145 group.

IncRNA mechanisms remain to be answered [38]. The lncRNA Prostate cancer gene expression marker 1 (PCGEM1) is overexpressed in $\mathrm{PCa}$, suggesting roles in proliferation, metastasis, and invasion [39]. In order to reveal the mechanisms regulating expression in $\mathrm{PCa}$, we have predicted PCGEM1 interaction with miR-145 using billogical information (Figure 1C), and futher investigated a possible interaction with the tumor suppressor miR-145. Co-transfection of LNCaP cells with miR-145 mimics or miR-145 inhibitor with psiCHECK-2-PCGEM1 significantly 


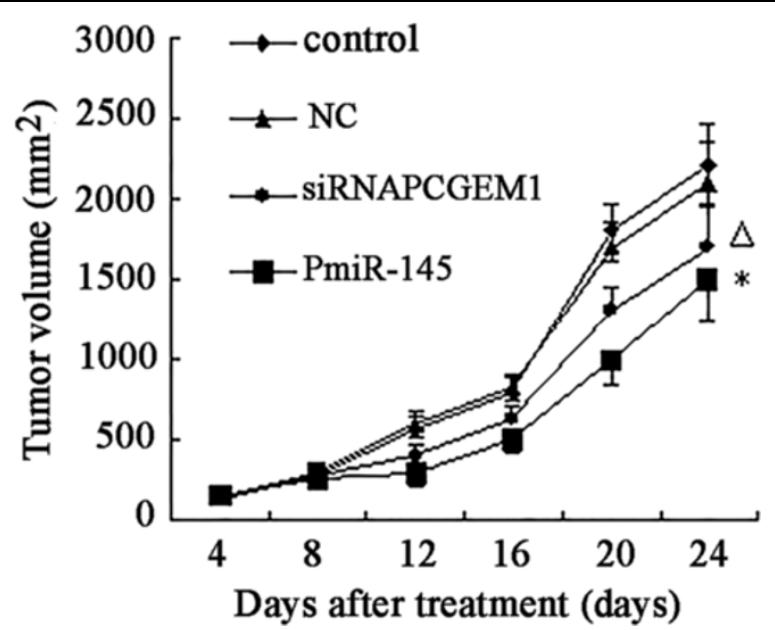

Figure 6 Effect of siRNA PCGEM1/pmiR-145 on prostate cancer xenografts. LNCaP tumor xenografts were established in male Athymic nude mice. Animals in the treatment arm received siRNA PCGEM1 (500 nM $/ \mathrm{kg}$ once daily) or pmiR-145 $(16 \mu \mathrm{g} / \mathrm{kg}$ once daily). Control mice received PBS (100 $\mu \mathrm{l} / \mathrm{kg}$ once daily). Negative Control mice received empty plasmid or scrambled sequence (16 $\mu \mathrm{g} / \mathrm{kg}$ once daily). After 20 daily treatments, tumors injected with siRNA PCGEM1 or pmiR-145 were significant smaller than control or NC group tumors $\left(P^{\Delta *}<0.05\right)$.

inhibited reporter gene activity but only miR-145 suppressed reported gene expression when transfected with empty psiCHECK-2 (Figure 1A, B). Thus, miR-145 may regulate $P C G E M 1$ expression by directly binding to target sites within the PCGEM1 sequence.

We then demonstrated a mutual inhibitory control relationship between PCGEM1 and miR-145 by selective siRNA-mediated PCGEM1 knockdown and miR-145 overexpression. Expression of PCGEM1 (locus 2q32) was detected in the androgen receptor-positive cell line LNCaP but not in noncancerous prostate lines or androgenreceptor negative Pca lines [23]. PCGEM1 overexpression in $\mathrm{LNCaP}$ cells promotes cell proliferation and a dramatic increase in colony formation, suggesting a role in cell growth regulation [24]. In contrast, miR-145 expression was low in all the prostate cell lines tested (PC3, LNCaP, and DU145) compared to the normal cell line RWPE-1, and in cancerous regions of human prostate tissue compared to adjacent normal prostate tissue [39]. To test the possibility of mutual negative regulation of PCGEM1 and $m i R-145$, we design a small interfering RNA targeting PCGEM1 and a vector for miR-145 overexpression (pmiR$145)$ and transfected these into LNCaP cells and normal RWEP-1 cells. RT-PCR results showed that knockdown of PCGEM1 in LNCaP cells increased miR-145 expression (Figure 2A) and that miR-145 overexpression reduced PCGEM1 expression (Figure 2B). Inhibition of PCGEM1 reduced $\mathrm{LNCaP}$ proliferation (Figure $3 \mathrm{~A}$ ), transwell migration and invasive capacity into Matrigel (Figures 5A, 6A), and the growth of solid tumors, possibly by promoted early apoptosis (Figure 4A). However, altering PCGEM1 expression had no significant effect on RWPE-1 cell growth, migration, or invasion (Figures 3, 4, 5, 6B). The proliferation, colony formation, and soft agar growth of liver cancer cells was reduced by inhibiting expression of the IncRNA TUC339 using an siRNA [40], while silencing HULC expression in hepatoma effectively inhibited the growth of liver cancer cells [41]. In contrast, siRNA gene silencing of MEG3 expression promote cell proliferation, whereas overexpression inhibited proliferation and promoted apoptosis [42]. Thus, individual lncRNAs can either promote or inhibit carcinogenesis. Selective knockdown and overexpression of lncRNAs may be feasible strategies to reduce tumor growth in a variety of tissue. Specifically, $m i R-145$ is a well documented tumor suppressor [43-46], and we successfully constructed an overexpressing vector that suppressed PCa cell growth with no observable effects on noncancerous prostate cells. Similarly, gain-of-function assays revealed that $m i R-145$ transfection inhibited cell proliferation, migration and invasion of PC3 and DU145 PCa cell lines [47].

While PCGEM1 is known to be overexpressed in PCa, it is unknown if overexpression directly causes hyperproliferation and (or) metastasis [24]. Fu [48] found that overexpression of PCGEM1 attenuated doxorubicininduced expression of $p 53$ and $p 21 \mathrm{Waf1/Cip1}$, and inhibited apoptosis of LNCaP cells. Petrovics [24] revealed that elevated PCGEM1 expression increased cell proliferation and $\mathrm{Rb}$ phosphorylation. However, to the best of our knowledge, no study has investigated PCGEM1 regulation by $m i R-145$. An siRNA PCGEM1 inhibited $\mathrm{LNCaP}$ cells growth and reduced migration and invasion, likely by raising the expression levels of $m i R-145$.

Indeed, we confirmed direct binding of $m i R-145$ to the PCGEM1 and demonstrated reciprocal regulation of these two transcripts. Moreover, miR-145-mediated suppression 
of PCGEM1 suppressed tumor growth in vivo and PCa cell proliferation and invasive capacity in vitro. In turn, Reciprocal regulation of PCGEM1 and miR-145 promote proliferation of LNCaP prostate cancer cells.

In conclusion, our study demonstrates reciprocal negative control of PCGEM1, a tumor-promoting long noncoding RNA, and the tumor suppressor $m i R-145$. This study highlights the interrelationship between two classes of non-coding RNAs. Both downregulation of PCGEM1 or overexpression of the miR-145 reduced the proliferation and invasive capacity of prostate cancer cells in vitro and in vivo.

\section{Abbreviations \\ IncRNA: Long non-coding RNA; PCGEM1: Prostate cancer gene expression marker 1; miRs: microRNAs; siRNA: Small interfere RNA; MTT: 3-(4,5-dimethylthiazol-2-yl)-2,4-diphenyl-tetrazo-lium bromide; FBS: Fetal bovine serum; DMSO: Dimethyl sulfoxide; PI: Propidium iodide.}

\section{Competing interests}

The authors declare that they have no competing interests.

\section{Authors' contribution}

$J H H$ and JZZ contributed equally to this work. YGL is the corresponding authors. JHH performed the experiments and analyzed the data. JZZ wrote the manuscript. YGL designed the study and revised the manuscript. LW and $\mathrm{ZPH}$ provided the reagents. YBL made the figures. All authors read and approved the final manuscript.

\section{Acknowledgement}

Grant support: This work was supported by grants from the Technical New Star of zhujiang, Pan Yu districts, Guangzhou. (NO: 2013-special-15-6.09;NO: 2013-special-15-6.10); Natural Science Foundation of China (81373520).

\section{Author details}

'Department of Laboratory, Central Hospital of Panyu District, 8 Fuyu Dong Road, shiqiao, Guangzhou, Guangdong 511400, P R China. ${ }^{2}$ The Second Affiliated Hospital of Guangzhou Medical University, Guangzhou 510620, China.

Received: 23 May 2014 Accepted: 25 August 2014

Published online: 10 September 2014

\section{References}

1. Li L, Sun R, Yundan L, Xinmin P, Zhaohui L, Peng B, Xiaofeng Z: Association between polymorphisms in long non-coding RNA PRNCR1 in 8q24 and risk of colorectal cancer. J Exp Clin Cancer Res 2013, 32:104-111.

2. Kotake Y, Nakagawa T, Kitagawa K, Suzuki S, Liu N, Kitagawa M, Xiong Y: Long non-coding RNA ANRIL is required for the PRC2 recruitment to and silencing of p15INK4B tumor suppressor gene. Oncogene 2010, 30:1956-1962.

3. Geisler S, Coller J: RNA in unexpected places: long non-coding RNA functions in diverse cellular contexts. Nat Rev Mol Cell Biol 2013, 14:699-712.

4. Ricardo BS, Thaís VP, Elvis TV, Carlos AS, Fernando SR, Hélio RM, Dimas TC, Aparecida MF: Gene expression profile of long non-coding RNA EVF-2 in medulloblastoma cell lines and tissue samples.BMC Proceedings. BioMed Central 2013, 7:61.

5. Wierzbicki AT: The role of long non-coding RNA in transcriptional gene silencing. Curr Opin Plant Biol 2012, 15:517-522.

6. Gutschner T, Diederichs S: The Hallmarks of Cancer: A long non-coding RNA point of view. RNA Biol 2012, 9:703-719.

7. Redis RS, Sieuwerts AM, Look MP, Tudoran O, Ivan C, Spizzo R, Zhang X, de Weerd V, Shimizu M, Ling H, Buiga R, Pop V, Irimie A, Fodde R, Bedrosian I, Martens JW, Foekens JA, Berindan-Neagoe I, Calin GA: CCAT2, a novel long non-coding RNA in breast cancer: expression study and clinical correlations. Oncotarget 2013, 4:1748-1762.
8. Ellis $B C$, Graham LD, Molloy PL: CRNDE, a long non-coding RNA responsive to insulin/IGF signaling, regulates genes involved in central metabolism. Biochim Biophys Acta 1843, 2014:372-386.

9. Sado T, Brockdorff N: Advances in understanding chromosome silencing by the long non-coding RNA Xist. Philos Trans R Soc Lond B Biol Sci 2013, 368:20110325.

10. Yang F, Bi J, Xue X, Zheng L, Zhi K, Hua J, Fang G: Up-regulated long noncoding RNA H19 contributes to proliferation of gastric cancer cells. FEBS $J$ 2012, 279:3159-3165.

11. Chen G, Wang Z, Wang D, Qiu C, Liu M, Chen X, Zhang Q, Yan G, Cui Q: LncRNADisease: a database for long-non-coding RNA-associated diseases. Nucleic Acids Res 2013, 41:D983-D986.

12. Liu X, Chen X, Xinfang Y, Tao Y, Bode AM, Zigang D, Ya C: Regulation of microRNAs by epigenetics and their interplay involved in cancer. J Exp Clin Cancer Res 2013, 32:96-104.

13. Png KJ, Yoshida M, Zhang XH, Shu W, Lee H, Rimner A, Chan TA, Comen E, Andrade VP, Kim SW, King TA, Hudis CA, Norton L, Hicks J, Massagué J, Tavazoie SF: MicroRNA-335 inhibits tumor reinitiation and is silenced through genetic and epigenetic mechanisms in human breast cancer. Genes Dev 2011, 25:226-231.

14. Leite KR, Tomiyama A, Reis ST, Sousa-Canavez JM, Sañudo A, Camara-Lopes $\mathrm{LH}$, Srougi M: MicroRNA expression profiles in the progression of prostate cancer-from high-grade prostate intraepithelial neoplasia to metastasis. Urol Oncol 2013, 31:796-801.

15. Paraskevopoulou MD, Georgakilas G, Kostoulas N, Reczko M, Maragkakis M, Dalamagas TM, Hatzigeorgiou AG: DIANA-LncBase: experimentally verified and computationally predicted microRNA targets on long non-coding RNAs. Nucleic Acids Res 2013, 41:D239-D245.

16. Song SJ, Poliseno L, Song MS, Ala U, Webster K, Ng C, Beringer G, Brikbak NJ, Yuan X, Cantley LC, Richardson AL, Pandolfi PP: MicroRNA-antagonism regulates breast cancer stemness and metastasis via TET-family-dependent chromatin remodeling. Cell 2013, 154:311-324.

17. Yang C, Wang C, Chen X, Chen S, Zhang Y, Zhi F, Wang J, Li L, Zhou X, Li N, Pan H, Zhang J, Zen $\mathrm{K}$, Zhang CY, Zhang C: Identification of seven serum microRNAs from a genome-wide serum microRNA expression profile as potential noninvasive biomarkers for malignant astrocytomas. Int J Cancer 2013, 132:116-127.

18. Hajjari M, Behmanesh M, Sadeghizadeh M, Zeinoddini M: Up-regulation of HOTAIR long non-coding RNA in human gastric adenocarcinoma tissues. Med Oncol 2013, 30:670.

19. Juan L, Wang G, Radovich M, Schneider BP, Clare SE, Wang Y, Liu Y: Potential roles of microRNAs in regulating long intergenic noncoding RNAs. BMC Med Genomics 2013, 6:S7.

20. Braconi C, Kogure T, Valeri N, Huang N, Nuovo G, Costinean S, Negrini M,

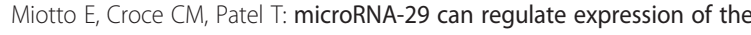
long non-coding RNA gene MEG3 in hepatocellular cancer. Oncogene 2011, 30:4750-4756.

21. Augoff K, McCue B, Plow EF, Sossey-Alaoui K: miR-31 and its host gene IncRNA LOC554202 are regulated by promoter hypermethylation in triple-negative breast cancer. Mol Cancer 2012, 11:5

22. Wang J, Liu X, Wu H, Ni P, Gu Z, Qiao Y, Chen N, Sun F, Fan Q: CREB upregulates long non-coding RNA, HULC expression through interaction with microRNA-372 in liver cancer. Nucleic Acids Res 2010, 38:5366-5383.

23. Srikantan V, Zou Z, Petrovics G, Xu L, Augustus M, Davis L, Livezey JR, Connell T, Sesterhenn IA, Yoshino K, Buzard GS, Mostofi FK, McLeod DG, Moul JW, Srivastava S: PCGEM1, a prostate-specific gene, is overexpressed in prostate cancer. Proc Natl Acad Sci U S A 2000, 97:12216-12221.

24. Petrovics G, Zhang W, Makarem M, Street JP, Connelly R, Sun L, Sesterhenn IA, Srikantan V, Moul JW, Srivastava S: Elevated expression of PCGEM1, a prostate-specific gene with cell growth-promoting function, is associated with high-risk prostate cancer patients. Oncogene 2004, 23:605-611.

25. Srivastava S, Srikantan V, Zou Z, Moul JW: Prostate-specific gene, PCGEM1, and methods of using PCGEM1 to detect, treat, and prevent prostate cancer. 2004, 12:7. U.S. Patent 6,828,4292[P].

26. Bao B, Ali S, Banerjee S, Wang Z, Logna F, Azmi AS, Kong D, Ahmad A, Li Y, Padhye S, Sarkar FH: Curcumin analogue CDF inhibits pancreatic tumor growth by switching on suppressor microRNAs and attenuating EZH2 expression. Cancer Res 2012, 72:335-345.

27. Lim L, Balakrishnan A, Huskey N, Jones KD, Jodari M, Ng R, Song G, Riordan J, Anderton B, Cheung ST, Willenbring H, Dupuy A, Chen X, Brown D, Chang AN, Goga A: MicroRNA-494 within an oncogenic microRNA megacluster 
regulates $\mathrm{G} 1 / \mathrm{S}$ transition in liver tumorigenesis through suppression of mutated in colorectal cancer. Hepatology 2014, 59:202-215.

28. Hart M, Wach S, Nolte E, Szczyrba J, Menon R, Taubert H, Hartmann A, Stoehr $R$, Wieland W, Grässer FA, Wullich B: The proto-oncogene ERG is a target of microRNA miR-145 in prostate cancer. FEBS J 2013, 280:2105-2116.

29. Jongen-Lavrencic M, Manova-Todorova K, Teruya-Feldstein J, Avigan DE, Delwel R, Pandolfi PP: The oncogenic microRNA miR-22 targets the TET2 tumor suppressor to promote hematopoietic stem cell self-renewal and transformation. Cell Stem Cell 2013, 13:87-101.

30. Yamasaki T, Yoshino H, Enokida H, Hidaka H, Chiyomaru T, Nohata N, Kinoshita T, Fuse M, Seki N, Nakagawa M: Novel molecular targets regulated by tumor suppressors microRNA-1 and microRNA-133a in bladder cancer. Int J Oncol 2012, 40:1821-1830.

31. Song SJ, Ito K, Ala U, Kats L, Webster K, Sun SM, Jongen-Lavrencic M, Manova-Todorova K, Teruya-Feldstein J, Avigan DE, Delwel R, Pandolfi PP: The oncogenic microRNA miR-22 targets the TET2 tumor suppressor to promote hematopoietic stem cell self-renewal and transformation. Cell Stem Cell 2013, 13:87-101.

32. Ozen M, Creighton CJ, Ozdemir M, Ittmann M: Widespread deregulation of microRNA expression in human prostate cancer. Oncogene 2008, 27:1788-1793.

33. Chen X, Gong J, Zeng H, Chen N, Huang R, Huang Y, Nie L, Xu M, Xia J, Zhao F, Meng W, Zhou Q: MicroRNA145 targets BNIP3 and suppresses prostate cancer progression. Cancer Res 2010, 70:2728-2738.

34. He JH, Li YG, Hang ZP, Wang L, Chun SY, He ML: Analysis biological information for PCGEM1 and speculate the molecular control network express in the prostate cancer. Chin Med Biotechnol 2013, 5:388-391.

35. He JH, Li YG, Chen SY, Wang L: Construction of the eukaryotic expression vector targeting hsa-miR-203 and its effects on proliferation and apoptosis of K562 cell lines. Chin J Clin Lab Sci 2012, 30:595-598.

36. Ponting $C P$, Oliver $P L$, Reik W: Evolution and functions of long noncoding RNAs. Cell 2009, 136:629-641.

37. Wilusz JE, Sunwoo H, Spector DL: Long noncoding RNAs: functional surprises from the RNA world. Genes Dev 2009, 23:1494-1504.

38. Liu D, Xu B, Chen S, Yang Y, Zhang X, Liu J, Lu K, Zhang L, Liu C, Zhao Y, Jiang H, Liu N, Chen M: Long Non-Coding RNAs and Prostate Cancer. J Nanosci Nanotechnol 2013, 13:3186-3194.

39. Ifere GO, Ananaba GA: Prostate cancer gene expression marker 1 (PCGEM1): a patented prostate-specific non-coding gene and regulator of prostate cancer progression. Recent Pat DNA Gene Sea 2009, 3:151-163.

40. Kogure $T$, Yan IK, Lin WL, Patel T: Extracellular Vesicle-Mediated Transfer of a Novel Long Noncoding RNA TUC339: A Mechanism of Intercellular Signaling in Human Hepatocellular Cancer. Genes Cancer 2013, 4:261-272.

41. Panzitt K, Tschernatsch MM, Guelly C, Moustafa T, Stradner M, Strohmaier HM, Buck CR, Denk H, Schroeder R, Trauner M, Zatloukal K: Characterization of HULC, a novel gene with striking up-regulation in hepatocellular carcinoma, as noncoding RNA. Gastroenterology 2007, 132:330-342.

42. Sun M, Xia R, Jin F, Xu T, Liu Z, De W, Liu X: Downregulated long noncoding RNA MEG3 is associated with poor prognosis and promotes cell proliferation in gastric cancer. Tumor Biol 2013, 12:1-9.

43. Guo W, Ren D, Chen X, Tu X, Huang S, Wang M, Song L, Zou X, Peng X: HEF1 promotes epithelial mesenchymal transition and bone invasion in prostate cancer under the regulation of microRNA-145. J Cell Biochem 2013, 114:1606-1615.

44. Kojima S, Enokida H, Yoshino H, Itesako T, Chiyomaru T, Kinoshita T, Fuse M, Nishikawa R, Goto Y, Naya Y, Nakagawa M, Seki N: The tumor-suppressive microRNA-143/145 cluster inhibits cell migration and invasion by targeting GOLM1 in prostate cancer. J Hum Genet 2014, 59:78-87.

45. Avgeris M, Stravodimos K, Fragoulis EG, Scorilas A: The loss of the tumoursuppressor miR-145 results in the shorter disease-free survival of prostate cancer patients. Br J Cancer 2013, 108:2573-2581.

46. Chiyomaru T, Tatarano S, Kawakami K, Enokida H, Yoshino H, Nohata N, Fuse M, Seki N, Nakagawa M: SWAP70, actin-binding protein, function as an oncogene targeting tumor-suppressive miR-145 in prostate cancer. Prostate 2011, 71:1559-1567.
47. Fuse M, Nohata N, Kojima S, Sakamoto S, Chiyomaru T, Kawakami K, Enokida H, Nakagawa M, Naya Y, Ichikawa T, Seki N: Restoration of miR-145 expression suppresses cell proliferation, migration and invasion in prostate cancer by targeting FSCN1. Int J Oncol 2011, 38:1093-1101.

48. Fu X, Ravindranath L, Tran N, Petrovics G, Srivastava S: Regulation of apoptosis by a prostate-specific and prostate cancer-associated noncoding gene, PCGEM1. DNA Cell Biol 2006, 25:135-141.

doi:10.1186/s13046-014-0072-y

Cite this article as: He et al:: Reciprocal regulation of PCGEM1 and miR-

145 promote proliferation of LNCaP prostate cancer cells. Journal of Experimental \& Clinical Cancer Research 2014 33:72.

\section{Submit your next manuscript to BioMed Central and take full advantage of:}

- Convenient online submission

- Thorough peer review

- No space constraints or color figure charges

- Immediate publication on acceptance

- Inclusion in PubMed, CAS, Scopus and Google Scholar

- Research which is freely available for redistribution

Submit your manuscript at www.biomedcentral.com/submit
() Biomed Central 